AJHSE Vol: 2 (2): 166-182, 2021

DOI: 10.52417/ajhse.v2i2.176

Accepted Date: Nov. 30, 2021

(C) 2021. CC License 4.0

www.ajhse.org

\title{
PARASITIC NEMATODE INFECTIONS OF ANURANS FROM A DERIVED SAVANNA BIOTOPE IN EDO STATE, NIGERIA
}

\author{
${ }^{* 1}$ Ozemoka, H. J. \& ${ }^{2}$ Aisien, M. S. O. \\ ${ }^{*} \& 2$ Laboratory of Parasitology Research, Department of Animal and Environmental Biology, Faculty of Life Sciences, University of \\ Benin, Benin City, Nigeria \\ *Corresponding Author's E-mail: habibatozemoka@gmail.com Phone: +2348073851517
}

\begin{abstract}
$\mathrm{A}$

s part of a broader study to increase the information of parasite infections of anurans from the savanna biotope, an investigation of the nematode parasites of anurans in Agbede, a location in the derived savanna of Edo State, Nigeria was undertaken from August 2007 to July 2008. Anurans were collected at night using the visual acoustic encounter survey (VAES) sampling method, dissected and examined for nematode infections. A total of 329 anurans belonging to sixteen taxa, were examined, of which 235 were infected with an overall prevalence of $71.43 \%$. Seasonal prevalences were $85.63 \%$ for wet season and $52.48 \%$ for the dry season $(\mathrm{p}<0.05)$. Ten nematode species, namely: Amplicaecum africanum, Cosmocerca ornata, Oswaldocruzia hoeplii, Physaloptera sp., Rhabdias africanus, Rhabdias sp., Camallanus dimitrovi, an unidentified oxyurid nematode, Ophidascaris larva, and an unidentified nematode were recovered from the hosts examined. The most common nematode species was Amplicaecum africanum (31.31\%), whereas the least common was an unidentified oxyurid nematode (0.30\%).Physaloptera sp. is a new record for the anurans of the derived savanna.
\end{abstract}

Keywords: Amphibians, anurans, nematodes, savanna, parasitic, Nigeria.

LICENSE: This article by African Journal of Health, Safety and Environment (AJHSE) is licensed and published under the Creative Commons Attribution License 4.0 International License, which permits unrestricted use, distribution, and reproduction in any medium, provided this article is duly cited.

COPYRIGHT: The Author(s) completely retain the copyright of this published article.

OPEN ACCESS: The Author(s) approves that this article remains permanently online in the open access (OA) model

QA: This Article is published in line with "COPE (Committee on Publication Ethics) and PIE (Publication Integrity \& Ethics)". 


\section{INTRODUCTION}

The various bioclimatic zones in Nigeria range from mangrove and fresh water swamps of the Niger Delta, to the rainforest, derived savannah, guinea savannah, Montane Forest and the Sahel savannah of the extreme North (Aisien et al., 2017). Investigations of the parasites of amphibians have extensively been carried out in the rainforest biotope (characterized by high levels of precipitation and atmospheric humidity which thus supports high canopy trees and thick undergrowth. These prevailing environmental and atmospheric conditions in the rainforest thus supports the study of the wide diversity of amphibians and their parasites in the country by various authors (Aisien et al., 2001, 2003, 2004a, b, 2009, 2011a, 2017; Imasuen and Aisien 2012, 2015. Amuzie et al.2018; Oniya and Adeyekun, 2019; Edo-Taiwo and Aisien 2020).

The savannah biotope is one characterized by shorter duration of rainfall (six months) when compared to the rainforest. The vegetation consists of grass and deciduous trees which offers very limited canopy cover. These conditions pose great threat to the survival of amphibians in this terrain and impair the life cycle and transmission of nematode parasites. Unlike anurans from the rainforest which have been studied in great detail for their helminth parasitic fauna, not so much attention has been devoted to anuran species from the savanna biotope. Information available in the literature about studies in the savannas of Nigeria include the studies by Avery (1971); Oladimeji (1990); Aisien et al. (2004); Iyaji et al. (2015); Anele et al. (2020).

The only report on the helminth parasites of anurans from the savanna mosaic zone of Edo State is that undertaken by Aisien et al., (2003) from five different locations, excluding Agbede and over a short duration. The latter limitation necessitated the present study to enable a detailed study, carried out over a longer duration. An earlier report dealt with the digenetic trematodes infecting anurans from this study area (Ozemoka and Aisien, 2020). In this paper we report the nematodes parasitizing anurans investigated at Agbede in the derived savannah of Edo State. The study yielded ten nematode parasites with Physaloptera sp. as a new record for the anurans of the derived savanna.

\section{MATERIALS AND METHODS}

The anurans examined in this study were collected from Agbede, a location in the derived savanna biotope in Edo State, from August 2007 to July 2008, using the Visual Acoustic Encounter Survey (VAES) techniques (Crump and Scott, 1994). Sampling was carried out at night on a monthly basis (once a month) for twelve months. Agbede is located in Etsako West Local Government Area of Edo State, Nigeria and lies roughly within latitude $06^{\circ} 50^{\circ} \mathrm{N}$ and $06^{\circ} 60^{\prime} \mathrm{N}$ and longitude $06^{\circ} 10^{\prime} \mathrm{E}$ and $06^{\circ} 20^{\prime} \mathrm{E}$ (Fig. 1). The anurans collected were identified according to Rödel, (2000). In the laboratory, the anurans were euthanized in Benzocaine solution, dissected and examined. The gastrointestinal tract (oesophagus, stomach, small intestine, large intestine and rectum) was examined for parasites. Other parts examined included the lungs, body cavity and the urinary bladder. The contents were mixed with $0.72 \%$ of $\mathrm{NaCl}$ solution and examined under a dissecting microscope. The nematode parasites recovered were fixed in hot $70 \%$ alcohol and preserved in the same medium. The worms were cleared in lactophenol and examined as temporary mounts. Photomicrographs of the parasites were taken (using a digital camera attached to a binocular microscope) from which we made line drawings. Prevalence rate of parasites was calculated as a percentage of the number of a particular host species infected with a specific helminth parasite divided by the total number of hosts examined. The 
mean intensity of infection refers to the number of parasites per host (calculated only for the infected hosts examined). Differences in the level of significance of infection according to season of infection, were determined using the one-way ANOVA at a 5\% level of significance. All statistical analysis were done using SPSS (Statistical Package for the Social Sciences) version 20 for windows.

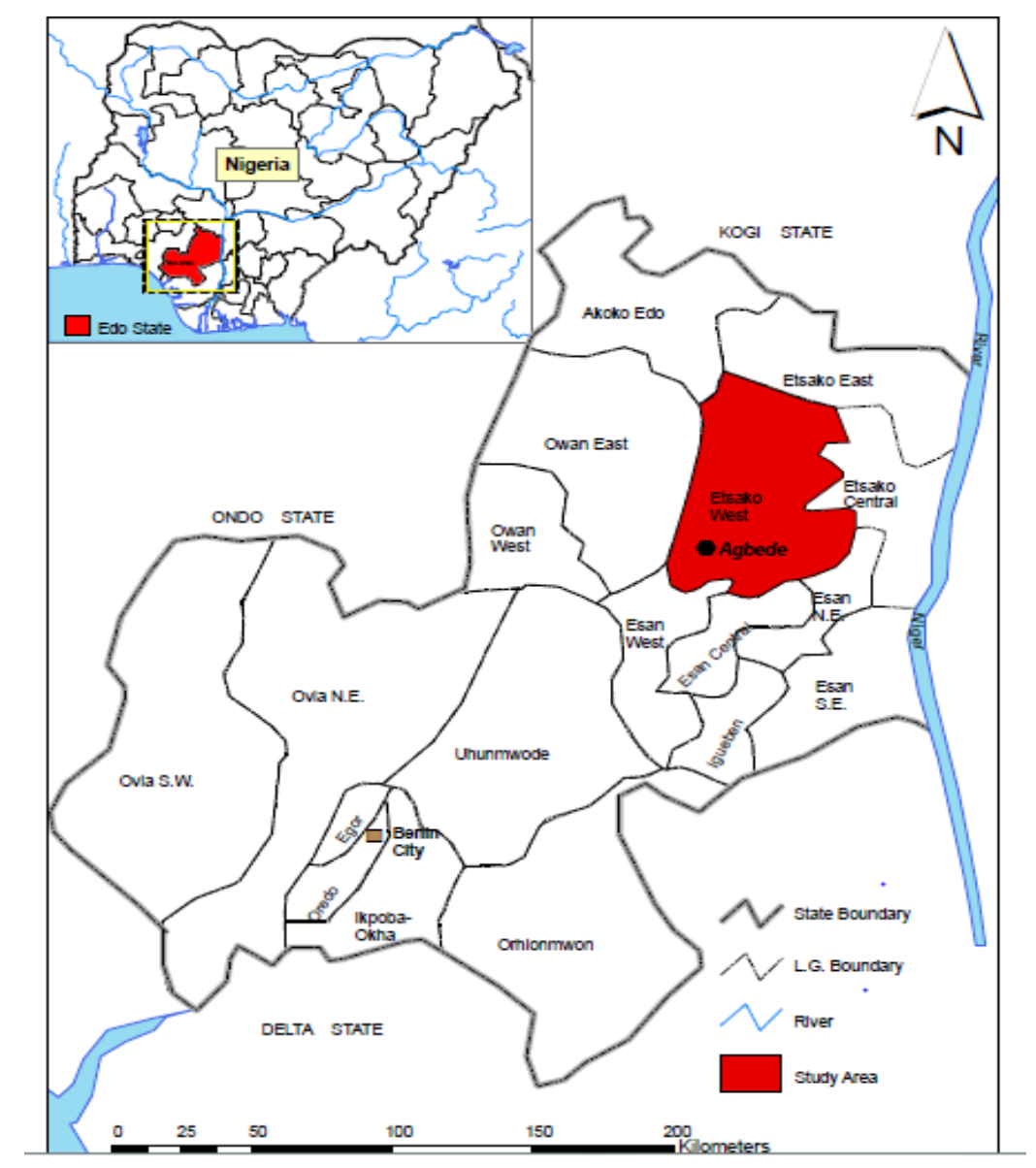

Figure 1. Map of Nigeria showing the study area.

\section{RESULTS}

In this study, 329 anurans which spread across four families, eight genera and sixteen species were examined. The species of anurans examined included Sclerophrys regularis, S. maculata, Sclerophrys sp. Arthroleptis poecilonotus, Arthroleptis sp. Leptopelis viridis, Hylarana galamensis, Hyperolius occidentalis, Ptychadena pumilo, P. bibroni, P.oxyrhynchus, P. schubotzi, P. mascareniensis, Ptychadena sp., Hoplobatrachus occipitalis and Phrynobatrachus natalensis. The study yielded ten nematode parasites as shown in Table 1. Overall prevalence of nematode parasites was $71.43 \%$ while infection intensity ranged from 3.00 to 17.33 parasites per infected host. The parasites encountered included: Amplicaecum africanum, Cosmocerca ornata, Oswaldocruzia hoeplii, Physaloptera sp., Rhabdias africanus, Rhabdias sp., Camallanus dimitrovi, unidentified oxyurid nematode, Ophidascaris larva and an unidentified nematode species (Table 1). Nematode parasites with appreciable prevalence included A. africanum (31.3\%), Oswaldocruzia hoeplii (21.58), C. ornata (27.54) and R. africanus (15.81\%). Prevalence for the remaining 
parasites ranged from $0.30-2.73 \%$. Mixed infections of $A$. africanum and $O$. hoeplii and A. africanum and Physaloptera sp., respectively were also encountered.

With respect to season, 188 anurans were examined in the wet season and 141 anurans in the dry season. Infection prevalence was higher in the wet season when 161 of the 188 anurans examined were infected with a prevalence of $85.63 \%$. Prevalence in the dry season was $52.48 \%$ (74/141) and these differences was statistically significant $(\mathrm{p}<0.05)$.

Some nematodes including A. africanum, O. hoeplii C. ornata, R. africanus, C. dimitrovi, Physaloptera sp. and Ophidascaris larva, occurred in both seasons in some hosts while others (e.g. the unidentified Oxyurid nematode) were recorded in the wet season while Rhabdias sp., the unidentified nematode species and mixed infection of A. africanum and Physaloptera sp. were recorded in the dry season (Table 2.)

Among the nematodes recovered, A. africanum, O. hoeplii and C. ornata were generalists as they infected multiple hosts. For example, Cosmocerca ornata infected thirteen of the sixteen anuran species examined. It had a prevalence of $27.40 \%$. One of the S. regularis examined harboured as many as 70 worms in the rectum. Oswaldocruzia hoeplii infected eight of the anuran species examined. The prevalence of this parasite ranged from $0.30 \%$ in $P$. pumilo, P. mascareniensis, H. galamensis and H. occipitalis, respectively, to $24.62 \%$ in $S$. regularis. One of the $S$. maculata examined harboured as many as 24 worms. Amplicaecum africanum parasitized six species out of the 16 species examined. The prevalence values for the parasite in most hosts were very low except for $S$. regularis (36.78\%). As many as 55 worms were recovered from the stomach of one of the S. regularis examined.

Table 1: Overall prevalence and mean intensity of nematode parasites in anurans from Agbede.

\begin{tabular}{|c|c|c|c|}
\hline Parasite & $\begin{array}{l}\text { Prevalence } \\
(\%)\end{array}$ & $\begin{array}{l}\text { Mean intensity } \\
( \pm \text { SEM })\end{array}$ & Infection site \\
\hline Amplicaecum africanum & 31.31 & $7.10 \pm 0.80$ & Stomach, s/intestine \\
\hline Oswaldocruzia hoeplii & 21.58 & $7.52 \pm 0.90$ & Stomach, s/intestine \\
\hline Cosmocerca ornata & 27.40 & $17.33 \pm 1.52$ & L/intestine/ Rectum \\
\hline Rhabdias africanus & 15.81 & $7.15 \pm 2.26$ & Lungs \\
\hline Rhabdias sp. & 0.61 & $3.5 \pm 0.50$ & Lungs \\
\hline Physaloptera sp. & 2.73 & $5.00 \pm 1.82$ & Small intestine \\
\hline Camallanus dimitrovi & 0.61 & $13.00 \pm 9.00$ & Small intestine \\
\hline Unidentified oxyurid nematode & 0.30 & 8.00 & Stomach \\
\hline Ophidascaris larva & 0.61 & 3.00 & Body cavity \\
\hline Unidentified nematode & 0.61 & 3.00 & Stomach, s/intestine \\
\hline $\begin{array}{l}\text { A. africanum \& O.hoeplii (mixed } \\
\text { infection) }\end{array}$ & 3.64 & $6.16 \pm 0.94$ & Stomach, s/intestine \\
\hline $\begin{array}{l}\text { A. africanum \& Physaloptera sp. } \\
\text { (mixed infection) }\end{array}$ & 0.30 & 15.00 & Small intestine \\
\hline
\end{tabular}


Table 2: Prevalence of nematode parasites in the anuran species from Agbede according to season.

\begin{tabular}{|c|c|c|c|c|}
\hline \multirow[t]{2}{*}{ Parasite } & \multicolumn{2}{|c|}{ Wet season } & \multicolumn{2}{|c|}{ Dry season } \\
\hline & $\begin{array}{l}\text { Prevalence } \\
(\%)\end{array}$ & $\begin{array}{l}\text { Mean intensity } \\
( \pm \text { SEM })\end{array}$ & $\begin{array}{l}\text { Prevalence } \\
(\%)\end{array}$ & $\begin{array}{l}\text { Mean intensity } \\
( \pm \text { SEM })\end{array}$ \\
\hline Amplicaecum africanum & 22.34 & $6.52 \pm 1.10$ & 43.97 & $7.44 \pm 1.13$ \\
\hline Oswaldocruzia hoeplii & 29.26 & $7.32 \pm 1.04$ & 11.34 & $8.18 \pm 1.50$ \\
\hline Cosmocerca ornata & 33.51 & $18.52 \pm 1.85$ & 19.14 & $14.60 \pm 2.60$ \\
\hline Rhabdias africanus & 14.90 & $10.80 \pm 4.00$ & 17.02 & $2.91 \pm 1.04$ \\
\hline Rhabdias sp. & - & - & 1.42 & $3.5 \pm 0.50$ \\
\hline Physaloptera sp. & 4.26 & $3.62 \pm 0.60$ & 1.42 & $10.50 \pm 8.50$ \\
\hline Camallanus dimitrovi & 0.53 & 4.00 & 0.71 & 22.00 \\
\hline Oxyurid nematode & 0.53 & 8.00 & - & - \\
\hline Ophidascaris larva & 0.53 & 3.00 & 0.71 & 3.00 \\
\hline Unidentified nematode & - & - & 1.42 & 3.00 \\
\hline $\begin{array}{l}\text { A. africanum \& O. hoeplii (mixed } \\
\text { infection) }\end{array}$ & 3.19 & $6.83 \pm 1.53$ & 4.25 & $5.50 \pm 1.18$ \\
\hline $\begin{array}{l}\text { A. africanum \& Physaloptera sp. } \\
\text { (mixed infection) }\end{array}$ & - & - & 0.71 & 15.00 \\
\hline
\end{tabular}

Rhabdias africanus was recovered from the lungs of S. regularis and S. maculata with higher prevalence $(13.87 \%)$ in S. regularis than in S. maculata (1.82\%). Two of the S. regularis examined harboured as many as 80 worms each in their lungs. Unidentified Rhabdias spp. were recovered P. bibroni and H. galamensis with prevalence values of $0.30 \%$ and $1.22 \%$, respectively. Four Ptychadena spp. harboured larval Physaloptera sp. with low prevalence values ranging from $0.30 \%$ to $1.52 \%$.

\section{DISCUSSION}

The number of species of anurans examined in this study, was sixteen which was more than the number that have been reported in other savannah locations (Avery, 1971; Aisien et al., 2003, 2004; Iyaji et al., 2015; Anele et al., 2020). Xenopus muelleri was the only anuran reported by Avery, (1971). Eleven species were recorded in the previous study undertaken by Aisien et al. (2003) in derived savannah of Edo State. In the Guinea savanna at new Bussa, Aisien et al. (2004) recorded and examined only four species. The numbers recorded were understandably so because of the short durations of the respective studies. Our record is however, still higher than the nine species reported by Anele et al. (2020) from Zaria in an investigation that spanned over two seasons.

The finding of 10 nematodes species from only one location (Agbede) as reported in this study brings two important points to the fore. There is the need to undertake studies of this nature over longer durations to ensure a proper capture of the parasite diversity present in the anurans of any biotope while also avoiding an over harvest of the anuran hosts. It also gives an insight into the influence of atmospheric humidity and vegetation cover in the transmission of nematode parasites. Although the derived savannah in Edo State has only six months of rainfall, the canopy cover is denser than other savanna biotopes further north. Therefore, anurans from areas with comparable rainfall data with lower canopy cover recorded lower nematode diversity: two in Katsina (Oladimeji et al., 19881990); four at New Bussa (Aisien et al., 2004); three from Ayingba (Iyaji et al., 2015) and four from Zaria (Anele et al., 2020)

One finding of interest in this study was the occurrence of Physaloptera sp. in five anuran species $(P$. pumilo, P. bibroni, P. oxyrhynchus, and P. schubotzi and H. occipitalis). This nematode was not recorded in the 
anurans investigated earlier by Aisien et al., (2003) in the savanna mosaic of Edo State. This nematode was first reported in the anurans from the Gelegele Forest Reserve in Edo State by Aisien et al., (2009) in P. bibroni, P. oxyrhynchus and P. longirostris, Thereafter, it has been reported in other anurans from different habitats, including, the brackish water environment (Uwasadhiuka, 2010; Aisien et al., 2015), freshwater creek biotope (Aisien et al., 2017), Guinea savanna (Iyaji et al., (2015) and cocoa plantations (Edo-Taiwo and Aisien, 2020). In this study, the parasite was recovered from Pty. schubotzi which thus becomes a new host record for the parasite. With regards to site of infection, Physaloptera sp. was recovered from the stomach of the infected hosts. This is in agreement with the reports of Iyaji et al., (2015), Gonzalez and Hamann (2006) and Edo-Taiwo and Aisien, (2020) who all reported the parasite from the stomach. This is in contrast to the report of Aisien et al., (2009), who reported the parasite from the small intestine. Iyaji et al., (2015) attributed the occurrence of the parasite in the small intestine to less nutrition in the stomach of captive host, which may have caused the movement of the parasite down to the small intestine.

Amplicaecum africanum infected more hosts (five) than was previously reported (four) by Aisien et al., (2003) in other locations of the savanna-mosaic in Edo State and three in the Guinea savanna (Aisien et al. (2004). The prevalence of (31. 31\%) in S. regularis was lower than the value recorded for this host in Auchi (43.5\%) but much lower when compared with the report for Igarra, Edo State, where 64.9\% prevalence was recorded for the same host (Aisien et al., 2003). A much higher prevalence (91.67\%) was reported by Iyaji et al. (2015) at Ayingba in the same host (formerly Amietophrynus regularis). Infections with this parasite have been reported in amphibians and reptiles of countries of East, West and Central Africa (Baker, 1987).

Cosmocerca ornata was the most dominant nematode infecting the anurans from Agbede, infecting 13 of the 16 host species examined. The generalist status of this parasite has similarly been reported in all the bioclimatic zones investigated in Nigeria (Aisien et al., 2001, 2003, 2004a, b, 2009, 2011a, 2017; Iyaji et al., 2015; Amuzie et al., 2018).

The two bufonid anurans in this study (S. regularis and S. maculata) were both infected with R. africanus with an overall prevalence of $15.81 \%$ and a mean intensity of 7.15 parasites/ infected host. This prevalence value was however lower than the values recorded in other locations in savanna-mosaic: $36.20 \%$ in Igarra, $28.20 \%$ in Agenebode in S. regularis. The prevalence value recorded in this study was however higher than the $1.4 \%$ recorded at Ihievbe $4.8 \%$ in Ozalla and 3.5\% in Ogbonna (Aisien et al., 2003). The Rhabdias spp. in Pty. bibroni and $H$. occipitalis need to be identified. Kuzim (2001) stressed the need for thorough examination of various Rhabdias specimens occurring in the different anurans investigated in Nigeria. Rhabdias spp.are lungworms which are problematic and can cause pulmonary damage and eosinophilic pneumonia in captive anurans (Christine and David 2007). Hoplobatrachus occipitalis is a new host record for Rhabdias.

Camallanus specimens were isolated from three specimens of $H$. occipitalis and one specimen of $\mathrm{S}$. regularis with a low prevalence value of $0.61 \%$. Higher prevalence values were reported in $H$. occipitalis $(D$. occipitalis) at Ihievbe (76.5\%) and Ogbonna (23.3\%) (Aisien et al., 2003). The authors also recovered a Camallanus sp. from B. regularis with a prevalence value of $0.2 \%$. From the findings of this study, there is need for appropriate 
description and identification of the parasite from S. regularis to determine if it is Camallanus dimitrovi or a different species.

Ophidascaris larva occurring in Pty. mascareniensis and Pty. pumilo has been reported from various anuran species in many locations (Aisien et al., 2001, 2003, 2004a, b, 2009, 2011a, 2015, 2017a, b; Imasuen and Aisien, 2015) and Agama colonarum (Odigwe, 1985). A recent study by Edo-Taiwo et al., (2020) reported high prevalence of this parasite in the body cavity of S. regularis (50\%), S. maculata (31.8) and Ptychadena oxyrhynchus $(50 \%)$ in Benin City. These parasites are believed to use anurans as transport or paratenic hosts (Imasuen et al., 2012). Adults of these nematodes have been recovered from snakes in Benin City, Nigeria by Awharitoma et al. (2017).

The mixed infection of A. africanum and Physaloptera sp. in P. schubotzi and of A. africanum and Oswaldocruzia hoeplii in $S$. regularis and in P. bibroni is a new phenomenon that have not been previously reported in the anurans from the savanna mosaic.

The wet season recorded a higher prevalence of nematode parasites which further buttresses our earlier assertion that rainfall and canopy cover are important factors in the transmission of nematode parasites. Some nematodes (A. africanum, Oswaldocruzia, hoeplii Cosmocerca ornata, Physaloptera sp. Ophidascaris larva, Rhabdias africanus and Camallanus dimitrovi) occurred in both seasons in some hosts, while some others were either recorded in the wet season (unidentified Oxyurid nematode) or in the dry season ( Rhabdias sp., unidentified nematode and mixed infection of A. africanum and Physaloptera sp.).

\section{CONCLUSION}

In conclusion, all the parasites recorded in this study have previously been reported by other authors in various biotopes. This is the first report of Physaloptera sp. from the savanna mosaic zone. Ptychadena schubotzi is a new host record for this parasite. Hoplobatrachus occipitalis is similarly a new host record for the Rhabdias sp. There is need for further research to properly describe and identify Rhabdias sp. from anurans in Nigeria. There is also the need for appropriate description and identification of the Camallanus specimens from $S$. regularis. The cooccurrence of A. africanum and Physaloptera sp. in Pty. schubotzi as well as A. africanum and Oswaldocruzia hoeplii in S. regularis and in Pty.bibroni is a new record.

\section{ACKNOWLEDGEMENT}

We acknowledge the cooperation of the Traditional Head of Agbede town, the Agbede Vigilante Group and the Agbede Police Division for providing security during the period of this investigation. Ibrahim Musa and Dauda Musa are also appreciated for their technical assistance during the field collections.

\section{REFERENCES}

Aisien, M. S. O., Ugbo, A. D., Ilavbare, A. N. and Ogunbor, O. (2001). Endoparasites of amphibians from southwestern Nigeria. Acta Parasitologica, 46 (4): 299- 305.

Aisien, M. S. O., Ajakaiye, F. B., Braimoh, K. (2003). Helminth parasites of anurans from the savannah- mosaic zone of south-western Nigeria. Acta Parasitologica, 48(1): 47-54. 
Aisien, S. O., Ayeni, E. and Ilechie, I. (2004). Helminth fauna of anurans from the Guinea savanna at New Bussa, Nigeria. African Zoology. 39 (1): 133-136.

Aisien, M. S. O., Ogoannah, S. O., Imasuen, A. A. (2009). Helminth parasites of amphibians from a rainforest reserve in south-western Nigeria. African Zoology, 44(1): 1-7

Aisien, M. S. O., Du Preez, L. H., Imasuen, A. A. (2011). Polystoma okomuensis n.sp. (Monogenea Polystomatidae) from Boulenger's stripped frog Phlyctimantis boulengeri (Peret) (1986) in Nigeria Journal of Helminthology. 85(2): 153-159.

Aisien, M. S. O., Nago, S. G. A. and Rödel, M. O. (2011). Parasitic infections of amphibians in the Penjari Biosphere Reserve, Benin. African Zoology. 46(2): 340 - 349.

Aisien, M. S. O., Uwagbae, M., Edo-Taiwo, O., Ima suen, A. A. and Ovwah, E. (2015). Pattern of parasitic infections in anurans from a mangrove community of the Niger Delta, Nigeria. The Zoologist. 13: 51-56.

Aisien, M. S. O. Ugbomeh, A. P. and Awharitoma, A. O. (2017). Parasitic infections of anurans from a freshwater creek community in Delta State, Niger Delta of Nigeria. Helminthologia. 54(2): 132 - 144.

Aisien, M. S. O. Sampson, S. A. and Amuzie, C. C. (2017). Parasitic infections of anurans from an urbanized rainforest biotope in Diobu, Port Harcourt, Nigeria. Nigerian Journal of Parasitology. 38(2): 292-297.

Aisien, M. S. O., Omereji, A. B. and Ugbomeh, A. P. (2017). Anuran parasites from three biotopes in Rivers State, Nigeria. Nigerian Journal of Parasitology. 38(1): 128- 135.

Aisien, M.S.O., Agbosua, E.;Imasuen, A.A and Daniel, O.S. (2017). Paratenic and definitive hosts of Diplopylidium triseriale from southern Nigeria rainforest biotope. Zoologist. 15: 50-55.

Amuzie, C. C. and Ekerette, I. B. (2017). Variations in parasitic helminths of Amietophrynus species collected from similar habitats, Rivers State, Nigeria. International Journal of BioSciences and Technology. 10 (10): 76 - 79.

Anele, E.U., Nock, I.H and Gadzama, I.M.K. (2020). Helminth parasites of anurans from Zaria, Northern Guinea savannah zone of Nigeria. Nigeria Journal of Parasitology. 41(2): 205-210.

Avery, R. A. (1971). A preliminary list of parasites collected from reptiles and amphibians in Northern Nigeria. British Journal of Herpetology, 4: 217-219.

Awharitoma, A.O. Ehiorobo, U.A.; Edo-Taiwo, O. (2017). Snakes species and their parasitic infections in Benin City, Nigeria. Nigerian Journal of Agriculture, Food and Environment. 13(2):158-162.

Baker, M.R. (1987). Synopsis of the nematode parasitic in amphibians and reptiles. Memorial University of New foundland Occasional Papers in Biology 11: 1- 325.

Christine L. Densmore and David Earl Green. (2007). Diseases of Amphibians. ILAR Journal. 48 (3):235 - 254

Crump, M.L and Scott, N.J, Jr. (1994). "Visual Encounter Surveys," In: W. R. Heyer, M. A. Donnelly, R. W. McDiarmid, A. C. Hayek and M. S. Foster, Eds., Measuring and Monitoring Biological Diversity, Standard Method for Amphibians, Smithsonian Institution Press, Washington DC. 84-92.

Durette-Desset, M. and Batcharov, G. (1974). Deux nematodes parasites d'Amphibiens du Togo. Annales de Parasitologie (Paris). 49(5): 567-576. 
Edo-Taiwo, O., Ovwah, E., Imasuen, A. A., Aisien, M. S. O. (2014). Larval strigeoid trematodes in anurans from southern Nigeria. Helminthologia. 51(4): 318- 322.

Edo-Taiwo, O. and Aisien, M.S.O. (2020). Parasitofauna of ground-dwelling anurans from cocoa plantations in Ugboke, Edo State, Nigeria. The Zoologist. 18: 8-18.

Gonzalez, C. E. and Hamann, M. I. (2010). First report of nematode parasites of Physalaemus santafecinus (Anura: Leiuperidae) from Corrientes, Argentina. Revista Mexicana d Biodiversidad. 81:677 - 687.

González, C.E. and Hamann, M.I. (2006). Helmintos parásitos de Leptodactylus bufonius Boulenger, 1894 (Anura: Leptodactylidae) de Corrientes, Argentina. Revista Española de Herpetología. 20: 39-46.

Imasuen A. A. and Aisien, M. S. O. (2012). Digenetic trematodes parasitic in anurans from rainforest biotopes in Edo State, Nigeria. The Zoologist. 10: 25- 33.

Imasuen, A. A. and Aisien, M. S. O. (2015). Helminth parasites of Silurana tropicalis from the Okomu National Park, Edo State, Nigeria. Nigerian Journal of Parasitology. 36 (1): 61-66.

Imasuen, A. A., Enabulele, E. E., Aisien, M. S. O. (2012). Helminth community of tree frogs at the Okomu National Park, Edo State, Nigeria. Nigerian Journal of Parasitology. 33(1): 1-8.

Imasuen, A.A., Ozemoka, H.J. and Aisien, M.S.O. (2012). Anurans as intermediate and paratenic hosts of helminth infections in the rainforest and derived savanna biotopes of southern Nigeria. International Journal of Zoology. Article ID 82370, 7 pages. Doi;10.1155/2012/823970

Iyaji, F.O, Medayedupin, I.T, Echi, P.C, Falola, O. and Omowaye, O.S. (2015). Gastrointestinal Helminth Parasites of Amietophyrnus Regularis, Bufonidae (African Common Toad) In Anyigba, Kogi State, Nigeria. Animal Research International. 12 (2): $231-240$

Kuzmin, Y.I. (2001). Rabdias africanus sp. nov. (Nematoda, Rhabdiasidae), a new species from the South African toads (Amphibia, Bufonidae), Acta Paraditologica. 46 (2): 148 - 150.

Odigwe, F. W. (1985). Survey of helmith parasites infecting Lizards in Benin City, Nigeria. Bachelor's Thesis University of Benin, Benin City, Nigeria. 35pp

Oladimeji, A.A., Abuh, S.J. and Sadiku, S.O.E. (1988- 90). The Nigeria Journal of Parasitology. 9-11:145-148.

Oniya, M.O and Adeyekun, A.L. (2019).Nematode parasites of Anurans from cocoa farms in Ondo State. International Journal of Tropical Disease and Health. 36(2): 1-11.

Ozemoka, H.J and Aisien, M.S.O. (2020). Digenetic trematodes infecting aurans from a derived savanna biotope in Edo State, Nigeria. Nigeria Journal of Parasitology. 41(2):184-186.

Roedel, M. O. (2000). Herpetofauna of West Africa: Amphibians of West African Savannah. Chimaera, Frankfurt. 1: $335 \mathrm{pp}$.

Uwasadhiuka J.B. (2010). Helminth parasites of amphibians in Koko, a brackish environment in Delta State. B.Sc. Thesis University of Benin, Benin City. 25pp 